\title{
New worries for the Wairarapa
}

\section{JANE MELSER}

Jane Melser is a new Wairarapa farmer. This comment was broadcast on National Radio's Sunday Supplement, 10 March 1996.

This week I drove with my daughters through dry, summer-hard country to the Wairarapa coast. We make the trip several times a year, and each time the creeping darkness of tens of thousands of acres of pinus radiata has encroached a little further onto the onceprosperous farmland.

I was poignantly reminded of a conversation $I^{\prime} d$ just had with a friend, after she'd spent a day delivering census papers out to the coast. Census enumerators are supplied with demographic figures from five years earlier to ensure they miss no-one in these remote areas. She reckoned that the population of this particular part of rural Wairarapa had fallen by at least $30 \%$ since 1991 . The farmers who have stayed hate the pine forests. Some of them now live in what amounts to forest clearings, without neighbours near at hand, going slowly mad with loneliness and claustrophobia. Pinus radiata has even changed the climate. At least one coastal farm has been experiencing winter frosts the last year or two - where no frost has lain since the beginning of time.

Where have all the farmers gone? I could hazard a guess, because my own farming family is seriously considering doing a runner when our lease expires in three years. The creeping contagion of the largely Japanese-owned pine forest isn't our problem. Ours is simply that, hard as we may work, fertilise, cull weak stock and try to ride the market, we can't make a buck. And we're not alone.

Lately, the combination of land prices inflated by factors including the growth of forestry and a thriving dairy industry - coupled with a strong dollar and the manic anti-inflationary mindset of the Reserve Bank (egged on by the Business Round Table) - has conspired to put sheep, beef and often arable farmers into deep trouble.

Let me give you some rough figures. An averagemedium hill country farm of, say, 800 acres, is still selling for $\$ 1$ million plus. This farm can probably support 4000 stock units, or maybe a little more. But there's no way that the farm, unless it's freehold, can support a family without substantial off-farm income - brought in by whichever members can rustle up another marketable skill. Not so long ago the same farm would not only have kept a large family more than comfortably - but it would have employed a stock manager, head shepherd, general hand and cadet into the bargain.

These days, falling meat and wool prices ensure that few farmers - even those whose land has been in the family for generations - are anything like debtfree. The mid-eighties subsidy removal, GATT uncertainties, and, perhaps most tellingly, the cringing attitude of successive agricultural bureaucracies towards adopting an aggressive single-desk marketing strategy, have seen to that. Our meat industry is plagued by internal competition among processors - all marketing their own lines to various offshore buyers, and cutting the suppliers' throats as they do.

What did you pay for your last beef roast? \$14 or $\$ 15$... ? Last week's beef schedule paid the farmer $\$ 1.55$ per kilo for prime beef. Cull cow has now dropped to below the dollar mark. Ask yourself where the rest goes!

A normal economic farm can carry some 600 cattle beasts - grossing $\$ 90,000$ per year. After fertiliser, animal health, contractor costs, and repairs and maintenance to fences, farm, plant and vehicles, you can knock out about $\$ 70,000$ of that. Yep $-\$ 70,000$ ! And no, debt repayment is not included in this figure. That, and the family's living expenses, are taken from the remaining $\$ 20,000$. I haven't just pulled this figure out of the air I'm indebted to Federated Farmers, who are monitoring the problem with growing alarm.

No wonder farmers are talking of walking off the land. No wonder they're selling out to the creeping blight of pinus radiata - taking a quick buck to invest in a more certain future. No wonder farmers' daughters and sons are studying commerce, medicine, law, homoeopathy - anything to escape the downward spiral. No wonder farmers are starting to show up in the suicide statistics.

I welcome a change of Minister. One can only hope that Lockwood Smith, as Minister of Agriculture, will put his money where his mouth is and encourage the development of a forceful and coherent marketing strategy for the New Zealand meat industry. Until this happens, farmers will continue to walk out, sell to forestry, or simply succumb to despair. I'll certainly and with great sadness - start looking for another job. And I wonder what, five years down the track, the census figures will show? 